\title{
Yüksek ET-1 ífadesinin Meme Bezi Fizyolojisi Üzerine Etkileri
}

\author{
Effects of Overexpression of ET-1 in Mammary Gland Physiology
}

\author{
Nadir Gül ${ }^{1}$ (D, Franz Theuring ${ }^{2}$ (D) \\ 'Humboldt Berlin Üniversitesi, Matematik ve Doğa Bilimleri Fakültesi, Berlin, Almanya \\ ${ }^{2}$ Charite Tıp Fakültesi Berlin, Farmakoloji Enstitüsü, Berlin, Almanya
}

ORCID ID: N.G. 0000-0003-1259-4910; F.T. 0000-0003-1736-0312

Cite this article as: Gul B, Theuring F. Yüksek ET-1 ifadesinin meme bezi fizyolojisi üzerine etkileri. Experimed 2021; 11(2): 120-9.

\section{öz}

Amaç: Endotelin (ET-1), kardiyovasküler sistemde güçlü bir vazokonstrüktör rolü olmasının yanı sıra birçok fizyolojik olayda kendini göstermektedir. ET-1 ekspresyonunun özellikle gebelik ve emzirme döneminde ortaya çıkması nedeniyle hem emzirme hem de yeni doğan için önemli bir işlevi olduğu düşünülmektedir. Bu çalışmada ET-1 transgenik fare modeli kullanarak meme bezi üstünde ET-1'in etkilerinin incelenmesi amaçlanmıştır.

Gereç ve Yöntem: Meme dokusunun farklı fizyolojik durumlarında (ergenlik, gebelik, laktasyon ve involusyon) ET-1 in etkisini incelemek üzere karşılaştırmalı bir çalışma gerçekleştirildi. Meme dokularından paralel kesitler hazırlanıp hematoksilen-eozin (HE) boyama ile mikroskobik inceleme yapıldı. Meme bezi gelişimi ve metabolizmasında önemli görevleri olan sinyal proteinlerinin (STAT5, AKT, STAT3) analizlerinde Western blot tekniği kullanıldı. Metabolik faaliyetlerde anahtar rolü olduğu bilinen genler (WAP, beta kazein, GLUT-1, SRBF1 Claudin 8, IL-6, LIF) gercek zamanlı polimeraz zincir reaksiyonu (RTPCR) tekniği ile analiz edildi.

Bulgular: ET-1 transgenik farelerde sırasıyla sekresyonel hasar, laktasyonel yetmezlik ve erken involusyon gibi patolojik bulgular tespit edildi. Transgenik grupta STAT5'in aktivasyonunun bu durumdan etkilenmediği ancak AKT protein seviyesinde düşüş olduğu saptandı. İnvolusyonda görülen STAT3 aktivasyonu transgenik farelerde laktasyonun 3. gününde tespit edildi. Ayrıca, RT-PCR analizleri ile transgenik farelerde yüksek ET-1 ifadesine bağlı olarak WAP'ın baskılandığını LIF protein ifadesinin belirgin bir şekilde arttığı tespit edildi.

Sonuç: Sadece gebelik ve laktasyon döneminde ifade edilen ET1 'in laktasyon ve yeni doğan için önemli bir işlevi olduğu düşünülmektedir. Yüksek ET-1 ifadesi meme fizyolojisinde önemli olduğu bilinen genlerin sentezini doğrudan etkileyerek laktasyonel yetersizliğe sebep olmuştur. Bu çalışmada ET-1 regülasyonunun meme bezi gelişiminde ve süt sekresyonu fonksiyonunda kritik bir rol oynadığı gosterilmiştir.

Anahtar Kelimeler: Endotelin, laktasyonel yetersizlik, WAP, LIF, erken involusyon, transgenik fare

\begin{abstract}
Objective: Alongside its role as a potent vasoconstrictor in the cardiovascular system, endothelin-1 (ET-1) is involved in numerous physiological processes. Its expression is thought to be an important function for both breastfeeding and newborns since it occurs especially during pregnancy and lactation. In this study, we projected the effects of ET-1 on mammary gland physiology employing ET-1 transgenic mice.
\end{abstract}

Material and Method: In this study, we compared the mammary glands of ET-1 transgenic mice with the control mice in different physiological states (adolescence, pregnant, lactation and involution). Parallel sections were prepared from mammary glands and microscopic examinations were performed with hematoxylin and eosin (HE)-staining. Western blot techniques were used in the analysis of signal proteins that have important functions in mammary gland development and the metabolism (STAT5, AKT, STAT3). Genes known to play a key function in metabolic activities (WAP, beta casein, GLUT-1, SRBF-1 Claudin 8, IL-6, LIF) were analyzed employing real-time PCR techniques.

Results: It was determined that ET-1 transgenic mice developed pathological conditions such as secretory damage, lactational failure and early involution, respectively. Our Western blot studies showed that STAT5 activation was not affected by this process in the transgenic group, but a decrease in AKT protein level was detected. We detected STAT3 activation seen in the involution process in transgenic mice only on the 3rd day of lactation. In addition, we found that WAP was suppressed due to high ET-1 expression and that LIF protein expression increased significantly, by real-time PCR analysis.

Conclusion: ET-1 expression is thought to be an important function for both lactation and newborns, especially during pregnancy and lactation. In this study, it was found that when ET-1 expression increases, it causes lactation failure in the mammary gland and directly affects the synthesis of genes known to be important in mammary physiology. Hereby, it was determined that the regulation of ET-1 plays a critical role in the development and secretory function of the mammary gland.

Keywords: Endothelin, lactational incompetence, WAP, LIF, precocious involution, transgenic mice 


\section{GíRiş}

Meme bezi, süt salgılama yeteneği kazanmış özel bir organdır. Gelişimi ve fonksiyonel özelliğini kazanması oldukça karmaşık bir sistematik farklılaşma ve hormonal düzenlemeler sayesinde olur. Meme bezi, epitel parankimi ve onu çevreleyen yağ stroması olarak iki yapısal komponentten oluşur. Parankim süt salgılanmasını sağlayan dallanmış salgı bezleri ve alveoler yapılardan meydana gelirken, stroma parankimin işlevini sağlayacak substrat ihtiyacını ve büyüyüp genişleyebileceği ortamı sağlar. Bu bağlamda meme bezlerinin yapısal ve fonksiyonel gelişimi altı kategoriye ayrılabilir: embriyonik, doğum sonrası, ergenlik, gebelik, laktasyon ve involusyon.

Gebelik ile birlikte östrojen ve progesteron hormonları epitel parankiminin gelişimini başlatır. Bu iki steroid hormonunun yanı sıra duktal gelişim ve alveogenezle ilgili olarak bir çok büyüme faktörü de rol almaktadır. Meme bezi doğum sonrası emzirmeye bağlı olarak sürekli süt üretimi ve sekresyonunu sağlayan bir fabrikaya dönüşür. Bu süreçte prolaktin sinyal kaskadı anahtar rol oynar. Yüksek seviyede salgılanan prolaktin hormonunun etkisiyle sinyal dönüştürücü ve transkripsiyon aktivatörü 5 (signal transducer and activator of transcription 5, STAT5) faktörünün etkinliği maksimum seviye ulaşır ve peynir altı suyu asidik proteini (whey acidic protein, WAP) beta kazein gibi farklı süt proteinlerinin sentezlenmesi sağlanır $(1,2)$. Prolaktin ayrıca sterol düzenleyici eleman bağlayıc protein 1 (sterol regulatory element binding factor 1, SREBF-1)'i aktive ederek çok sayıda lipid metabolizması genlerinin sentezlenmesini sağlar (3). Hem gebelik hem de laktasyon dönemlerinde protein kinaz B olarak da bilinen AKT sentezi ve aktivasyonu hücresel yaşam ve anti-apoptotik sinyal yollarında etki gösterir (4).

İnvolusyon, emzirmenin bitmesi veya sütten kesilme ile başlayan bir süreçtir. Emzirmenin kesilmesi ile uyarılan lobuloalveoler yapı küçülmeye başlar. Bu durumla birlikte laktojenik hormonlar hızla azalıp yerini lösemi inhibitör faktörü (leukemia inhibitor faktor, LIF) ve interlökin (IL)-6 gibi apoptoz aktivatörü sitokinlerin artışına bırakarak bu süreçte anahtar rolu üstlenen STAT3 proteininin aktivasyonuna neden olurlar. STAT3 kaskadı meme bezinde apoptoz ve involusyon için elzemdir (5-7). İnvolusyon ile meme bezi süt salgılama kabiliyetini kaybederek yapısal ve fizyolojik olarak gebelik öncesi duruma döner.

Endotelin-1 (ET-1) vasküler homeostazın korunmasının yanı sıra geniş fizyolojik etkilere sahip küçük bir vazoaktif peptiddir (8). ET-1 sentezleyen hücrelerin depolama ve salgılama özellik- leri olmamasından dolayı ET-1'in sentezi transkripsiyon seviyesinde kontrol edilir (9).

Kardiyovasküler bir molekül olarak bilinen ET-1 kardiyovasküler sistemle ilgisi olmayan çok sayıda fizyolojik süreçte de yer almaktadır. Özellikle sütte ET-1'in varlığı, pek çok peptid ve büyüme faktörü gibi, hem emziren anne hem de yeni doğanın fizyolojisinde önemli bir rolü olduğunu düşündürmektedir (10). Ayrıca meme bezi gelişiminde ve fizyolojisinde anahtar hormonlardan biri olan prolaktin hormonunun ET-1'in ifadesini güçlü bir şekilde indüklediği (11) tespit edilmiş ve ET-1'in gen ifadesinin özellikle gebelik sırasında başlayıp laktasyon dönemi boyunca devam ettiği önceki çalışmalarda belirtilmiştir (12). Bu bağlamda, ET-1'in meme bezi gelişimi üzerine etkisi ve olası fonksiyonel rollerini aydınlatmak üzere ET-1 transgenik fareler kullanarak bu çalışma tasarlanmıştır.

\section{GEREÇ VE YÖNTEM}

\section{Hayvan Deneyleri}

Bu çalışmada NMRI (Harlan-Winkelmann, Padernborn) kontrol grubu fareler ile Franz Theuring tarafından geliştirilen NMRI kökenli homozigot insan ET-1 transgenik fareler kullanılmıştır. Standart fare yemi ve içme suyu ile beslenen fareler 12 saat gün ve 12 saat gece döngüsüne sahip, sıcaklığın $20-22^{\circ} \mathrm{C}$ ve rutubetin \%50-70 arasında tutulduğu, patojenden arıtılmış bir ortamda yetiştirilmiştir.

Meme dokuları, anterior abdominal duvar, kaslar ve deriden ayrıştırılarak toplanmıştır. Dokular hızlı bir şekilde soğuk yıkama tampon solüsyonu ile yıkanıp histoloji çalışmaları için formalin solüsyonu (Sigma) ile muamele edilip $4^{\circ} \mathrm{C}$ de saklandı. Moleküler biyoloji uygulamaları için işaretli tüplere alınan numuneler sıvı nitrojenle muamele edilip çalışmalar için $-20^{\circ} \mathrm{C}$ de saklanmıştır.

Hayvan deneyleri iki grup altında gercekleştirilmiştir. Ergenlik döneminden başlayarak sırasıyla gebelik, laktasyon ve involusyon dönemlerini kapsayan birinci grup farelerin meme dokularından elde edilen numuneler ile karşılaştırmalı gen ifade analizleri, göreceli protein fosforilasyon seviyeleri ve histolojik çalışmalar için doku preparatları hazırlanmıştır. Numuneler Tablo 1'de belirtilen 4 farklı fizyolojik durumda toplanmıştır.

İkinci grupta, laktasyon süresi boyunca 10 kontrol grubu farenin emzirdiği 70 yeni doğan ile 17 ET-1 transgenik farenin emzirdiği 119 yeni doğanın gelişimleri günlük ağırlık ölçümleri yapılarak takip edilmiştir. Ayrıca, laktasyon sırasında oluşan ağırlık farkının genetik bir farklıııtan kaynaklanıp kaynaklanmadığını

Tablo 1. Histolojik ve moleküler biyoloji uygulamalarının gerçekleştirildiği birinci grup farelerin dağılımları.

\begin{tabular}{lcccccc}
\hline & Ergen & \multicolumn{2}{c}{ Gebe } & & Laktasyon & İnvolusyon \\
\cline { 2 - 7 } & 8. hafta & 10. gün & 18. gün & 3. gün & 14. gün & 14. gün \\
\hline Kontrol (WT) & 6 & 6 & 7 & 6 & 70 & 7 \\
\hline Transgen (ET-1) & 6 & 6 & 7 & 6 & 10 & 7 \\
\hline
\end{tabular}


anlamak üzere çalışmayı takiben her iki gruptan olgunluğa erişmiş 20 adet dişi farenin ağırlıkları tekrar kontrol edilmiştir.

Bütün hayvan deneyleri Alman hayvan koruma kanunlarına (Tierschutzgezetz) uygun bir şekilde gerçekleştirilmiştir.

\section{Histolojik Çalışmalar}

Birinci grup farelerden elde edilen meme bezleri, oda sıcaklığında minimum 12 saat PBS ( $\mathrm{pH} 7.4$ ) içinde \%4 (w/v) paraformaldehit ile fikse edildi. Fiksasyon işleminden sonra doku örnekleri parafin bloklara gömüldü ve $5 \mathrm{~mm}$ 'lik kesitler alınmıştır. Gebe $(n=26)$ ve laktasyon $(n=32)$ dişilerden toplam 232 meme bezi örneği (her meme bezinden 2 slayt ve her bir fareden 4 meme bezi) analiz edilmiştir. Meme bezleri hematoksilen-eozin (HE) ile boyanmıştır.

\section{Gen İfade Analizleri}

Meme bezi gelişiminde ve fonksiyonunda anahtar rol üstlenen bir grup genlerin göreceli ifadeleri gercek zamanlı polimeraz zincir reaksiyonu (RT-PCR) yöntemleri ile analiz edilmiştir. Bu genler, süt proteinleri olarak bilinen beta kazein ve WAP genlerinin yanı sıra süt salgılayan hücrelerin tight-junction'larında görev alan Claudin-8, süt salgılayan hücrelere glukoz transportunu üstlenen merkezi proteinlerden biri olan GLUT-1 geni, yine aynı şekilde süt salgılayan hücrelerde lipit metabolizmasını düzenleyen SRBF-1 genleridir. Ayrıca süt salgılama fonksiyonunun bittiği meme bezinde STAT3 aktivatörü ve involusyon belirteci olarak bilinen IL- 6 ve LIF genleri de gen ifade analizlerinin kapsamında çalışılmıştır.

Toplam RNA, standart guanidinyum tiosiyanat-fenol-kloroform ekstraksiyonu (Trizol, Invitrogen) kullanılarak hızlı bir şekilde dondurulmuş dokulardan elde edilmiştir. cDNA sentezinden önce, tüm ham RNA örnekleri rutin olarak DNase1 (TurboDNase, Ambion) ile muamele edilmiştir. cDNA, üreticinin protokolüne göre oligo (dT) 18 primerler ile (Promega) MMLV ters transkriptaz enzimi kullanılarak oluşturulmuştur.

Kantitatif analiz için Ensembl gen veri tabanı, Primer3 ve web tabanlı algoritmalar (NCBI Blast, çoklu hizalama) kullanılarak tasarlanmıştır (Tablo 2). Kantitatif PCR'larda, MX3700p RT-PCR sisteminde (Stratogen) SYBR Green mastermix (Applied Biosystems) kullanılarak her bir numune 3'lü set olarak çalışılmıştır.

\section{Western Blot Çalışmaları}

Meme bezlerinin gelişimini ve fonksiyonel değişimlerini koordine eden sinyal proteinlerinin aktivasyonlarını Western blot teknikleri kullanılarak tespit edilmiştir. Özellikle alveogenezi ve süt sentezini koordine eden STAT5 proteininin yanı sıra hücre ölüm ve yaşam kaderini belirleyen AKT ve involusyon sürecini koordine eden STAT3 proteinlerinin göreceli fosforilasyon seviyeleri çalışılmıştır.

Birinci grup farelerden elde edilen dondurulmuş meme bezi örnekleri bir havan yardımı ile sıvı nitrojenle toz haline getirilmiştir. 100 mg doku örnekleri oda sıcaklığında 15 dakika süreyle $600 \mu \mathrm{l}$ üre lizis tamponunda homojenize edilmiştir. Çözdürme işleminden sonra numuneler oda sıcaklığında 45 dakika süreyle 13000 rpm'de santrifüj yapılmıştır. Süpernatanlar yeni tüplere yerleştirilerek protein konsantrasyonu Bradford metodu ile (Biorad) ölçülmüştür. SDS PAGE'den önce numuneler, $4 x$ yükleme tamponu (Roth) ile $95^{\circ} \mathrm{C}^{\prime}$ de 5 dakika kaynatılarak denatüre edilmiş, örnekler elektroforezi takiben

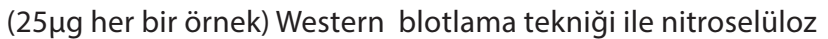
membran (Amersham) üzerine blotlanmıştır. TBS içinde bloke

Tablo 2. RT-PCR gen ifade analizlerinde kullanılan primerler.

\begin{tabular}{|c|c|c|}
\hline Gen Adı & F- Primerler (5'-3') & R- Primerler (5'-3') \\
\hline Beta- Kazein (fare) & CTCCACTAAAGGACTTGACAGC & AGTGAACTTTAGCCTGGAGCAC \\
\hline Claudin-8 (fare) & CGC TGG AGG AGC ACT GTT CTG TTG & CGG CGT GGA AAC TCC GTT GA \\
\hline GAPDH (fare) & CTTCACCACCATGGAGAAGGC & GGCATGGACTGTGGTCATGAG \\
\hline GLUT-1 (fare) & CCAGCTGGGAATCGTCGTT & CAAGTCTGCATTGCCCATGAT \\
\hline HPRT (fare) & CATTATGCTGAGGATTTGGAAAGG & CTTGAGCACACAGAGGGCTACA \\
\hline IL6 (fare) & TGTACTCCAGGTAGCTATGG & GTTCTCTGGGAAATCGTGGA \\
\hline LIF (fare) & GGCAACCTCATGAACCAGATCA & GCAAAGCACATTGCTGAGGAGGC \\
\hline PPET-1(fare) & ССССАСТСТTСТGАССССТT & ACTCCTTGTCCATCAAGGAAGAAC \\
\hline PPET-1 (insan) & ATCAGAAGAAGTTCAGAGGAACAC & GAAGGTCTGTCACCAATGTGCT \\
\hline PPET-1 (fare/ insan) & CAAGGAGCTCCAGAAACAGC & GATGTCCAGGTGGCAGAAGTA \\
\hline SRBF-1 (fare) & AGGCGGCTCTGGAACAGA & TGTCGTTCAAAACCGCTGTG \\
\hline WAP (fare) & TAGCAGCAGATTGAAAGCATTATG & CAACGCATGGTACCGGTGTCA \\
\hline
\end{tabular}


Tablo 3: Western Blot çalışmalarında kullanılan antikorlar.

\begin{tabular}{llll}
\hline Antikor & Orjin ve Dilüsyonlar & Moleküler ağırlık kDa & Referans \\
\hline pAKT (tyr 334) & RPA 1/1000 Dilüsyon & 60 & Santa Cruz Biotech. \\
\hline AKT & RPA 1/1000 Dilüsyon & 60 & Santa Cruz Biotech. \\
\hline B-Actin & GPA 1/2000 Dilusyon & 43 & Santa Cruz Biotech. \\
\hline pSTAT3 (tyr 705) & RPA 1/1000 Dilüsyon & $79 / 86$ & Cell signaling Tech. \\
\hline STAT3 & RPA 1/1000 Dilüsyon & $79 / 86$ & Cell signaling Tech. \\
\hline pSTAT5 (tyr 694) & RPA 1/1000 Dilüsyon & 90 & Cell signaling Tech. \\
\hline STAT5 & RPA 1/1000 Dilüsyon & 90 & Cell signaling Tech. \\
\hline Antimouse lg & Rabbit, HRP linked polyclonal antibody & -- & Dakocytomation. \\
\hline Antirabbit lg & Goat, HRP linked polyclonal antibody & -- & Dakocytomation. \\
\hline *RPA = Rabbit Polyclonal Antibody, GPA=Goat Polyclonal Antibody, HRP: Horseradish peroxidase &
\end{tabular}

edici çözelti ile \%0,1 Tween 20 ile 1 saat oda sıcaklığında inkübe edilmiştir. Membranlar, $4^{\circ} \mathrm{C}$ 'de gece boyunca bloke edici çözelti içinde seyreltilmiş birincil antikor ile inkübe edilmiştir (Tablo 3). Spesifik sinyaller ikincil antikor uygulamasını takiben ECL (Amersham) solüsyonu vasıtasıyla saptanmıştır.

\section{İstatistiksel Yöntemler}

Hayvan deneyleri: Elde edilen sonuçlar Student's t-testi kullanılarak istatistiksel olarak değerlendirilmiştir.

Göreceli gen ifade değerleri: Meme bezi cDNA'sının seri seyreltilmesiyle oluşturulan standart bir eğri vasıtasıyla GAPDH'ye karşı normalize edildi. İstatistiksel analizler için pair wise fixed reallocation randomizasyon testi (REST) (29) uygulanmıştır.
Western blot çalışmaları: Membran görüntüleri dijitalleştirildikten sonra özel bir yazılımla (AlphaEaseFC); dansitometrik veriler bir istatistiksel analiz programı (GraphPad Prism) ile analiz edilmiştir. Sonuçlar Student's t-test yöntemi kullanılarak istatistiksel olarak değerlendirilmiştir.

\section{BULGULAR}

RT-PCR gen ifade analizlerinde meme bezinde gebelik ( 10 . ve 18. gün) ve laktasyon (3. ve 14. gün) dönemlerinde ET-1 transgen ifadesi (Şekil 1A) ve toplam prepro-endothelin-1 (PPET- 1) (Şekil 1B) tespit edilmiştir. Ergen grubunda sadece fare ET-1 sentezlenirken involusyon periyodunda ET-1 ifadesine rastlanmamıştır (Şekil 1). Göreceli ifade analizlerinde ise toplam PPET-1 transgenik farelerde gebelik periyodunda 5,
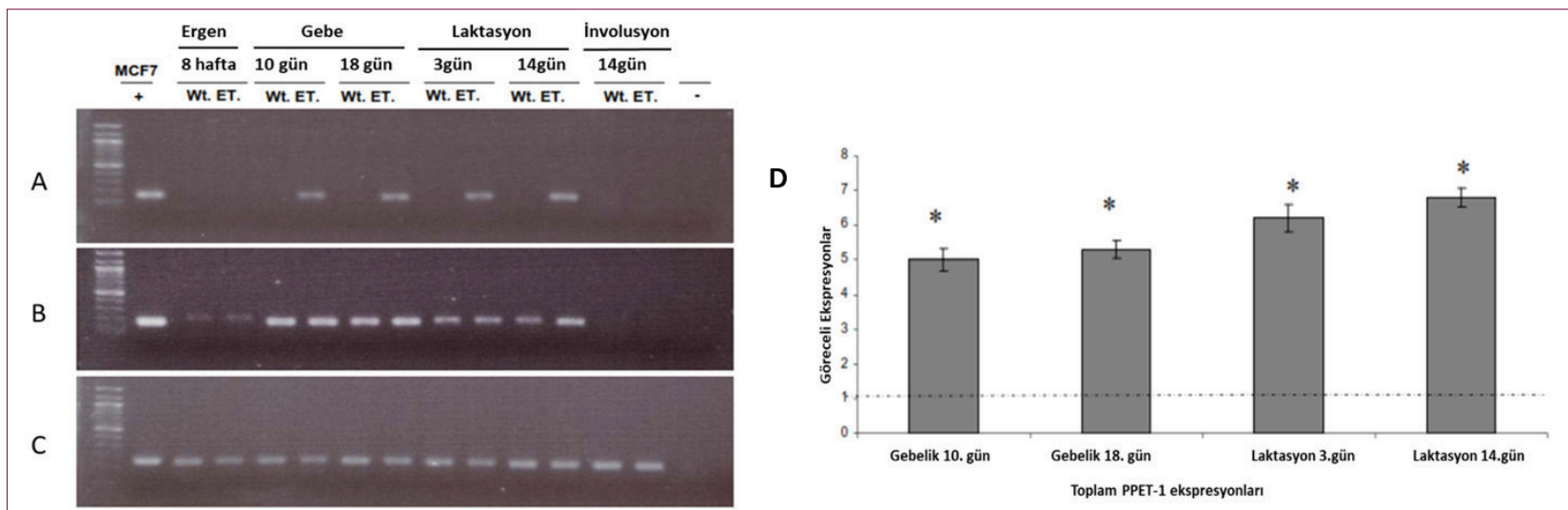

Şekil 1. ET-1'in meme bezinin dört farklı fizyolojik durumdaki ifadesi: Ergen (8. hafta), gebelik (10. ve 18. günler), laktasyon (3. ve 18. günler) ve involusyon (14. gün) A: PPET-1 (insan) transgen gen ifadesi, B: PPET-1 (insan/fare) gen ifadesi, C: Hipoksantinguanin fosforibosiltransferaz (HPRT) (fare) kontrol gen ifadesi. Çalışmada MCF7 hücre hattı PPET-1 (insan) için pozitif kontrol ve negatif kontrol olarak dd $\mathrm{H}_{2} \mathrm{O}$ kullanılmıştır. D: Transgenik farelerde göreceli toplam PPET-1 ifade seviyeleri. Kontrol grubu (Wt) PPET-1 ifade seviyeleri 1 olarak düzenlenmiştir (çizgili hat) ; ${ }^{*}=\mathrm{p}<0,05$ (REST) her bir grup için $\mathrm{n}=4$. 
laktasyon periyodunda 6 kat daha fazla ifade edildiği tespit edilmiştir (Şekil 1D).

Normal bir gebelik süreci geçiren transgenik farelerin yeni doğanlarında mortalitenin dikkat çekecek şekilde yüksek olduğu gözlenmiştir. Emzirmenin daha ilk günlerinde ölü yeni doğan- ların karınlarında süt tespit edilemediğinden, laktasyonel yetersizliği daha iyi tanımlayabilmek üzere laktasyon süresi boyunca yavrularda kilo artışı takip edilmiştir. Şekil 2A da görüldüğü gibi yeni doğanların ağırıklarında bir fark yokken 3. günden itibaren transgenik grupta anlamlı bir şekilde düşük kilo kazanımı tespit edilmiştir. Laktasyon sonunda yavrular arasından seçilen

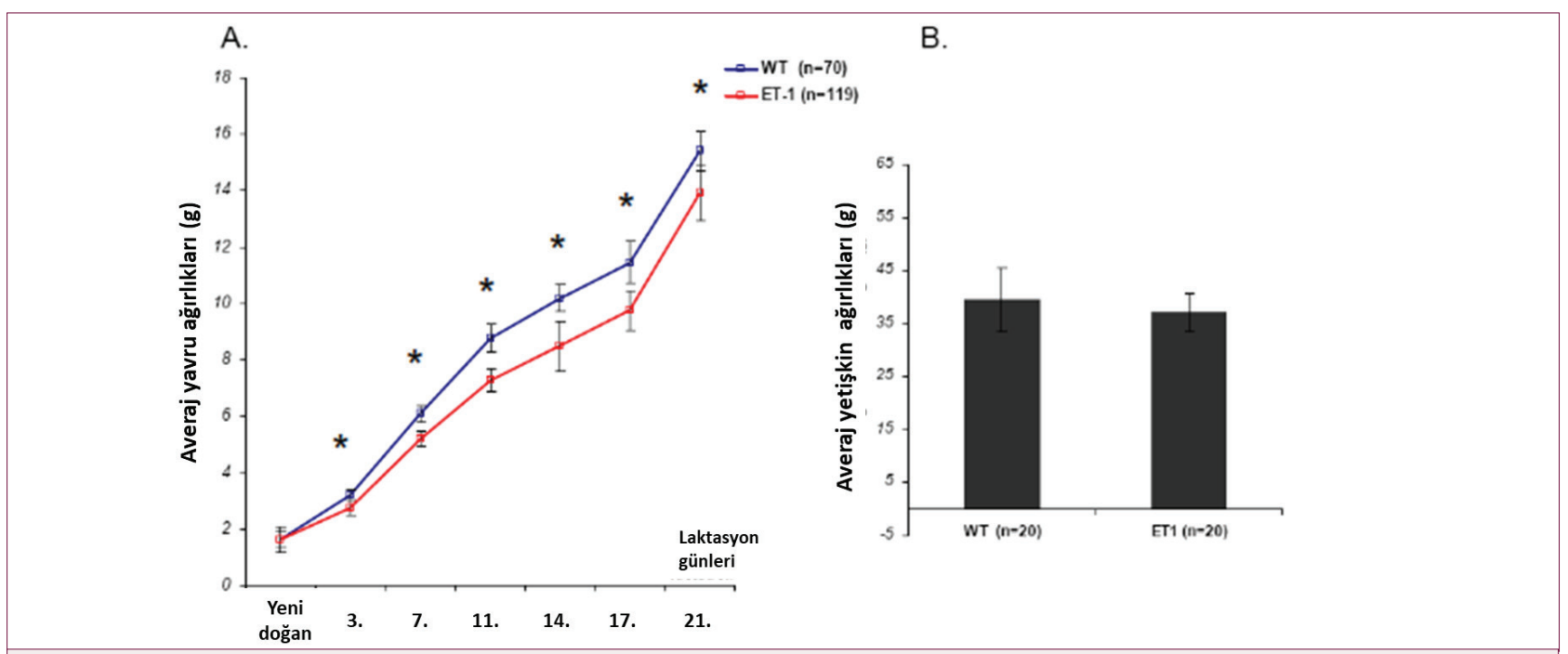

Şekil 2. A. Laktasyon periyodu süresince yeni doğandan başlayarak yavru farelerde kilo kazanımı. Kontrol grubu $n=70$; ET-1 transgen grubu $n=119 ;{ }^{*}=p<0.05$ (Student's t-test). B. Yetişkin farelerde ortalama ağırlık (gruplar arasında bir fark bulunmamaktadır).

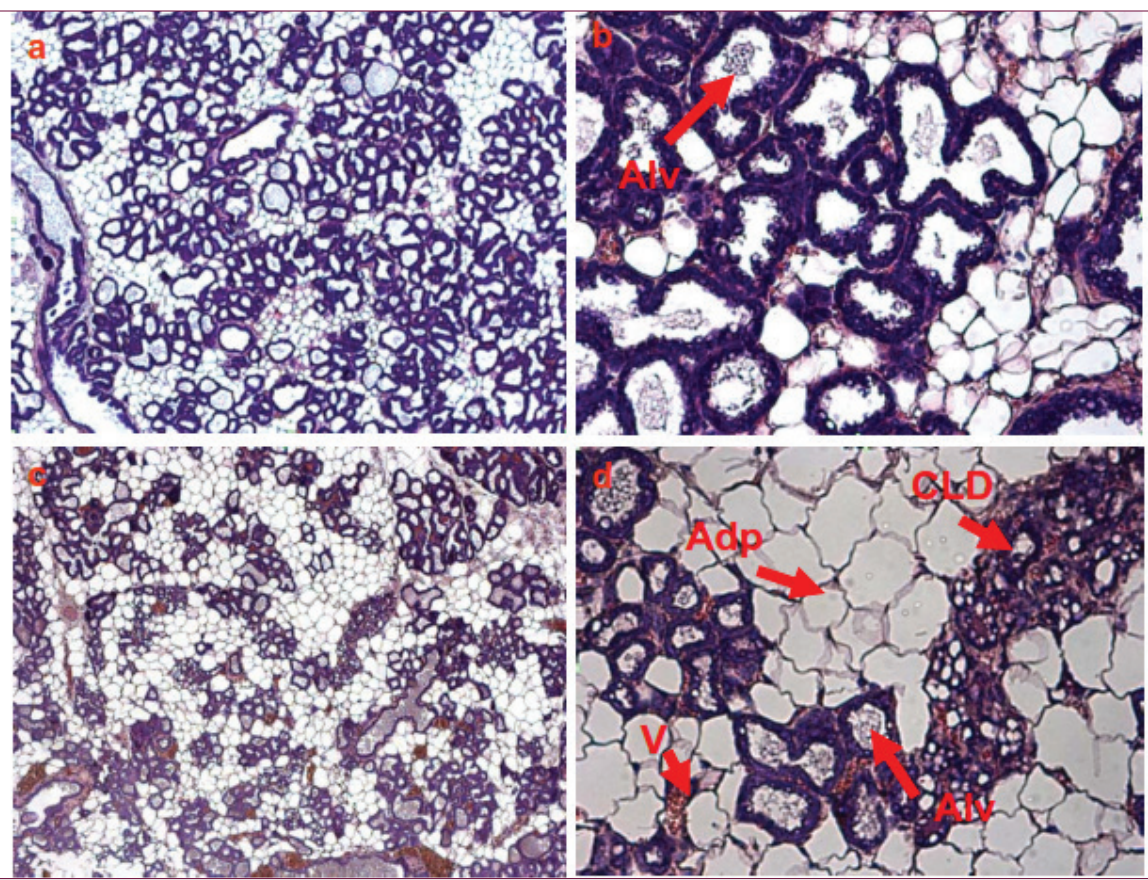

Şekil 3. Laktasyon 3. gün meme bezi histolojisi. Kontrol grubu a. (x50 büyütme) ve b. (x200 büyütme) ET-1 transgenik grup c. (x50 büyütme) ve d. (x200 büyütme). a ve b histogramlarında görüldüğü gibi doğum sonrası emzirmeye bağlı olarak adipositler (Adp) metabolize edilmiş, alveoli genişlemiş ve bütün dokuyu kaplamıştır. Alveoller (Alv) arasında ince bir tabaka olarak dikkati çeken kırmızı kan hücreleri kan damarlarını belirtmektedir (V). c ve d histogramlarında sitoplazmik lipid damlacıkları (CLD) ve zayıf alveloler genişleme görülmektedir. 
her bir grup için 20 fare yetişkinliğe ulaştığında tekrar tartılmış ancak kontrol grubu ile transgenik grup arasında istatistiksel bir fark görülmemiştir.

Histolojik çalışmalarda ET-1 transgenik farelerde düşük seviyede duktal büyüme, tıkanmış alveoli ve düşük genişleme kapasitesi ile beraber artmış adiposit birikimi tespit edilmiştir. Ayrıca alveol içinde sıkışmış bir şekilde bulunan sitoplazmik lipid damlacıkları (CLDs) ET-1 transgenik farelerde sekresyonal bir hasar olduğunu göstermektedir (Şekil 3).

Histolojik bulgulara ek olarak önemli süt proteinlerinden WAP gen ifadesinin hem gebelikte hem de laktasyon dönemlerinde baskılanmış olduğu tespit edilmiştir. Ayrıca beta kazein gebelik sırasında normal seviyede ifade gösterirken laktasyon periyodunda ise ifadesi baskılanmıştır (Şekil 4).

Süt üretimi ve salgılanması çeşitli ve karmaşık bir dizi gelişimsel ve fizyolojik taşıma ve salgılama süreçlerinden oluşmaktadır. Sıkı bağlantı (tight junction) proteinlerinin sentezinde veya regülasyonlarındaki bir hasar sekresyon aktivitesine doğrudan etki eder (13). Ayrıca glukoz ve lipid transport süreçlerindeki herhangi bir olumsuz durum meme bezinde hızlı bir şekilde etkisini sekresyonal hasar olarak gösterir. Bu süreçlerin substan- siyal regülasyonları mRNA seviyesinde gerçekleşmektedir (1417). Bu nedenle sekresyon hasarını daha iyi karakterize etmek üzere Claudin-8, GLUT-1, SREBF-1 ifade seviyeleri laktasyon 3. günde çalışılmıştır. SREP-1 ifadesinde ciddi bir artış gözlemlendiği için bu genin ifade seviyesi ayrıca gebelik 18. gün için de çalışılmıştır (Şekil 5B).

Gebelik ve laktasyon dönemlerinde fare meme epitel hücrelerinin terminal farklılaşmasında STAT5 aktivasyonu gerekmektedir (3). Prolaktinin aktive ettiği STAT5 alveolar gelişmenin yanı sıra WAP gen ifadesini de sağlar (13). Transgenik farelerde gelişen sekresyonel hasarın ve baskılanmış WAP gen ifadelerinin moleküler mekanizmalarını daha iyi anlayabilmek için STAT5 aktivitesinin nispi fosforilasyon seviyeleri immünblot teknikler ve dansitometrik analizler ile incelenmiştir.

Gebeliğin 18. gününde ve laktasyonun 3. gününde STAT5 proteinin aktivasyonunda anlamlı bir fark bulunmamıştır (Şekil 6).

Gebelik sırasında meme bezindeki epitel hücrelerinin sekresyon özelliği kazanması için gerekli fonksiyonel değişimde AKT anahtar bir rol almaktadır (14). AKT ayrıca laktasyon sırasında süt sentezini düzenlemektedir (18).
A

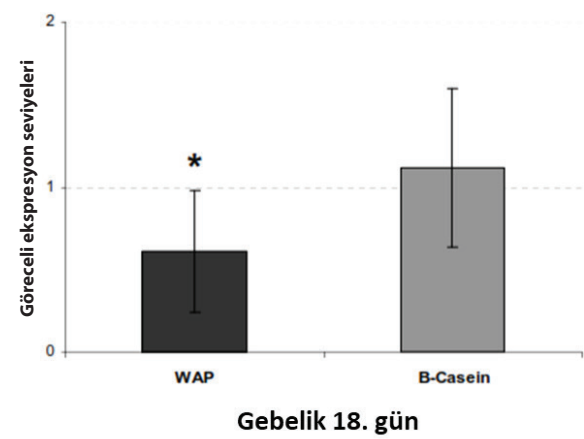

B

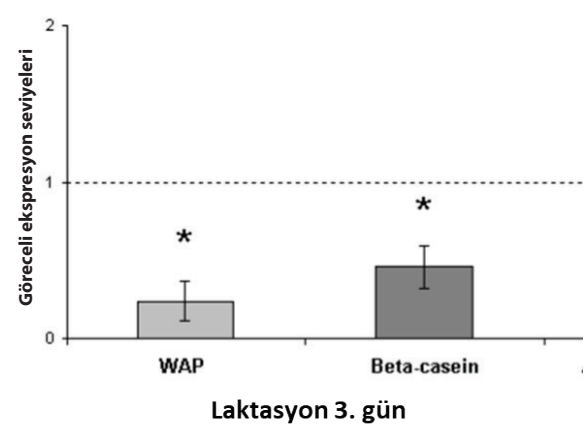

Şekil 4. Önemli süt proteinlerinin göreceli gen ifade analizleri. A. Gebelik, B. Laktasyon dönemi kontrol grubunun ifade seviyesi 1 olarak düzenlenmiştir (çizgili hat). ${ }^{*}=p<0,05$ (REST). Her bir grup için $n=5$.

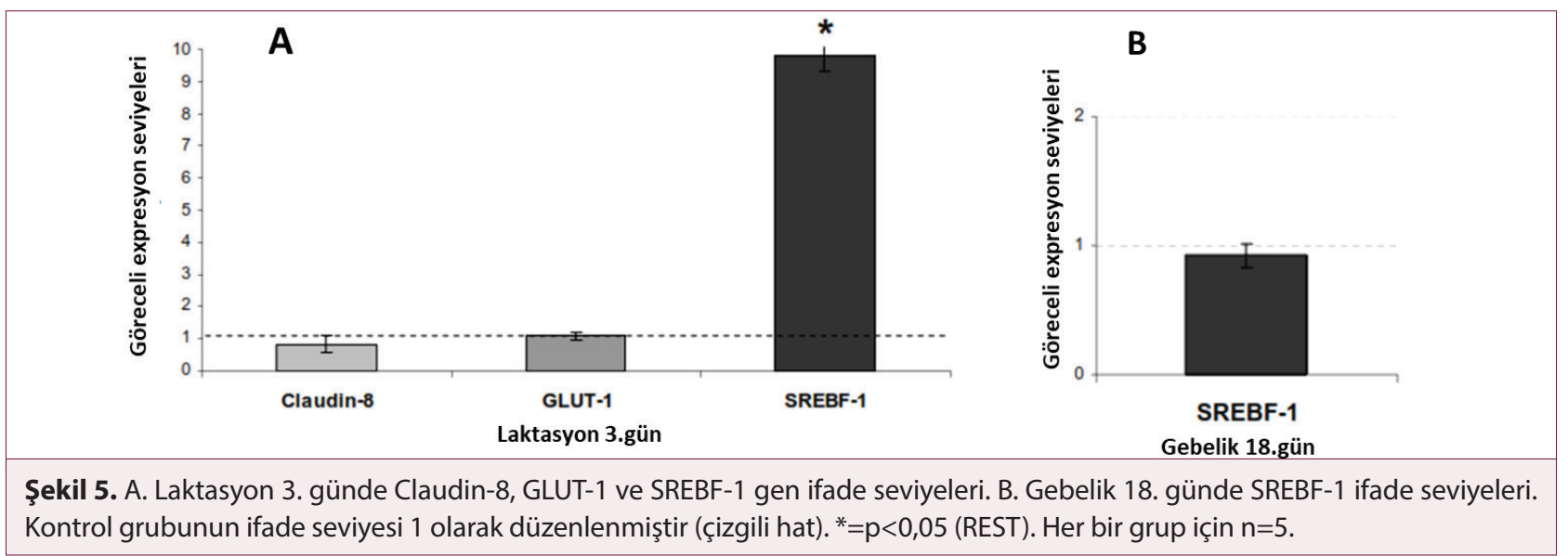



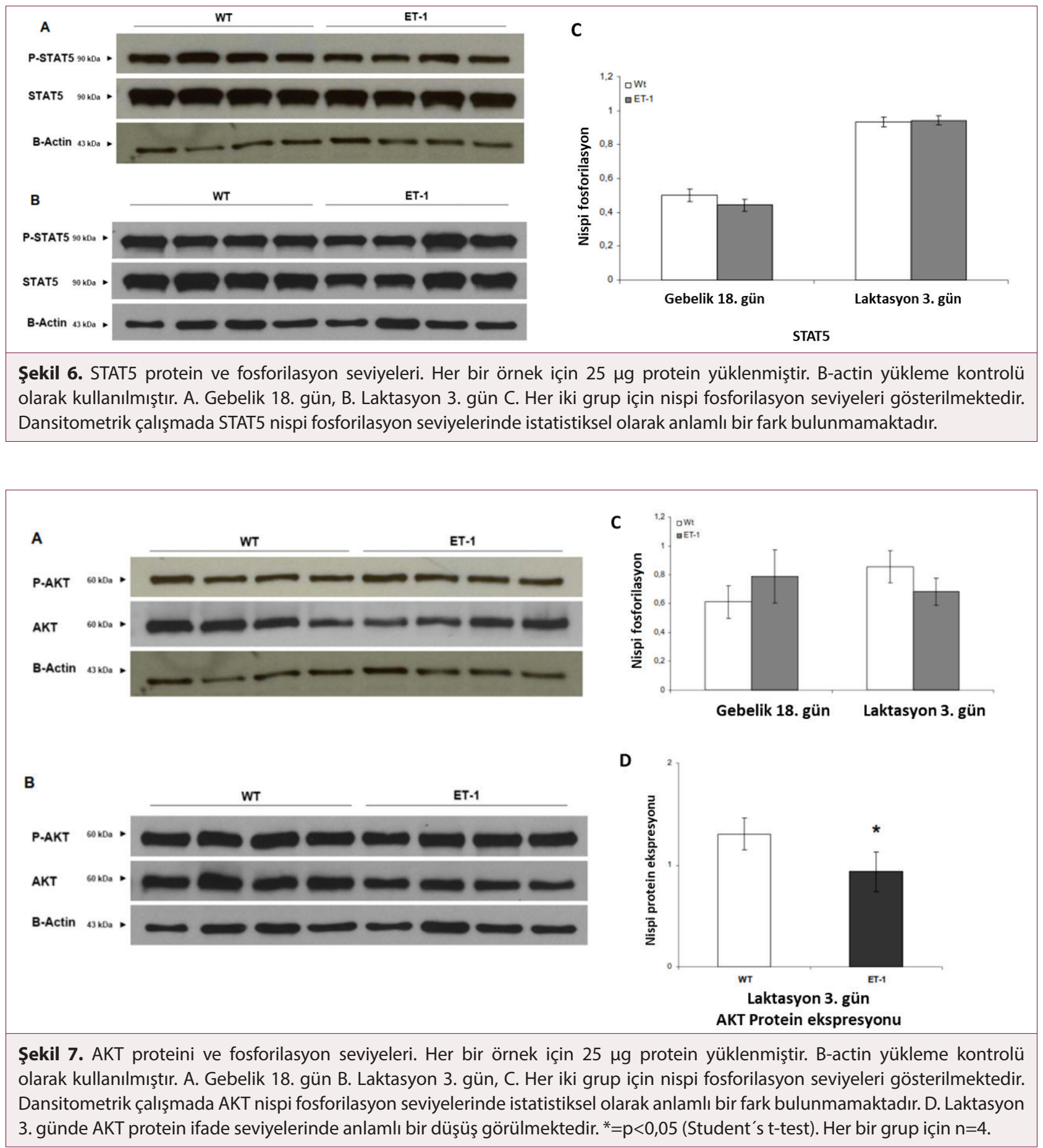

Bu fonksiyonel ve metabolik etkilere ek olarak, AKT, salgı epitel hücreleri için bir hayatta kalma faktörü görevi görür. Gen ifadesi involusyon ile hızlıca düşüş gösterir (19). Bu bağlamda sekresyon hasarı gelişen transgenik farelerde AKT aktivasyonu ve protein seviyeleri karşılaştırmalı olarak analiz edilmiştir. (Şekil 7).

Her ne kadar nispi aktivasyon olarak AKT kontrol grubu ile bir fark göstermiyor olsa da AKT'nin bu anlamlı düşüşü sekresyo- nel hasarın bir sonucu olarak erken bir involusyon sürecinin başladığını düşündürmüştür (7). Bu bağlamda involusyon başlangıcında anahtar rol oynayan STAT3 sinyal sistemini kontrol ederek hipotezimizin sağlaması yapılmıştır (Şekil 8).

ET-1 transgenik farelerde erken involusyonun bir kanıtı olarak STAT3 proteininin aktivasyonu tespit edilmiştir. Ancak bu aktivasyon sekresyon hasarından dolayı mı yoksa STAT3 proteinlerinin aktivasyonunda görev alan diğer başka involus- 

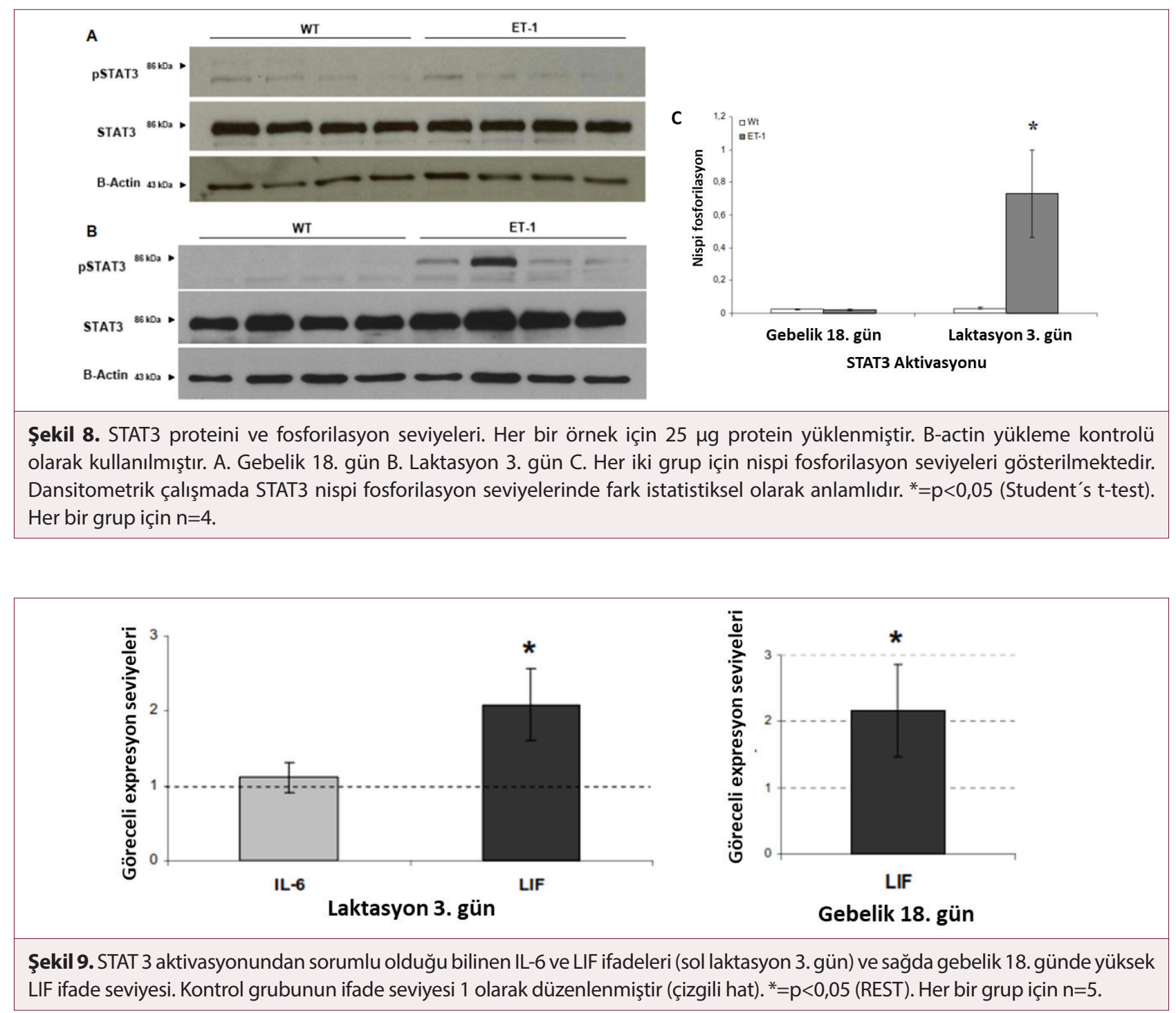

yon belirteçlerinin ifade seviyelerindeki değişimden dolayı mı olduğunun belirlenmesi gerekmekteydi. Birçok çalışmada IL-6 ve LIF sitokinlerinin STAT3'ü aktive ettiği gösterilmiş̧ir $(7,19,20,21)$. Bu sayede ET-1 yüksek ifadesi ile alakalı bir ipucu bulunabileceği öngörülerek IL-6 ve LIF sitokinlerinin karşılaştırmalı gen ifade analizleri önce laktasyonun 3 . gününde test edilmiştir. LIF geninin normalden 2,5 kat daha fazla sentezlendiği tespit edilince, aynı çalışma gebeliğin 18. günü için tekrarlanmıştır. Her iki farklı fizyolojik durumda da ET-1 transgenik farelerde LIF geni normalin üstünde bir ifade göstermektedir (Şekil 9).

\section{TARTIŞMA}

ET-1 transgenik fareler laktasyonel yetmezlik olarak adlandırılan bir fenotip geliştirmiştir. Bu hasar fareler doğum yaptıktan hemen sonra ortaya çıkmıştır. Doğumu takiben birçok ölü yavru fare tespit edilmiş ve makroskopik olarak transgenik yavrula- rın karınlarında süt olmadığı gözlenmiştir. Bu durum laktasyonel hasarın ilk belirtisi olmuştur.

Bu çalışmada öncelikle endotelin sisteminin meme bezlerinde aktif olduğunun tespit edilmesi hedeflenmiştir. Şekil 1'de açıkça görüldüğü gibi endojen ET-1 ifadesi 8. hafta ergen farelerde gözlenirken transgen ET-1 ifadesi sadece gebelik ve laktasyon dönemlerinde ortaya çıkmıştır. Endojen ET-1 ile transgen ET-1 arasındaki bu fark genomik ET-1 klonunda bazı promotör bölgelerin eksik olduğu yönünde yorumlanabilir. İnvolusyon periyodunda da herhangi bir ET-1 sentezi tespit edilemediğinden dolayı çalışmamı sadece gebelik ve laktasyon dönemleri ile sınırlandırılmıştır. Ayrıca RT-PCR analizleri bu iki fizyolojik dönemdeki transgenik fareler için toplam (fare ve insan) ET-1 ifadesinin kontrol grubu farelere göre yaklaşık 6 kat arttığını göstermektedir. Bu durum bize yüksek ET-1 ifadesinin meme bezi üzerine etkilerini analiz etmemize olanak veren bir model oluşturmuştur. 
Transgenik farelerde laktasyonel yetmezlik olarak ortaya çıkan fenomeni teyit etmek üzere transgenik farelere kontrol grubu yavru fareler foster edilerek kontrol grubu ile eşit miktarda yavru fare emzirme imkânı sağlanmıştır. Şekil 2'de yeni doğandan laktasyon sonuna kadar yavru farelerin büyümeleri gözlemlenmiştir. Başlangıçta ağırlık farkı gözlenmemesine rağmen laktasyon sonuna kadar transgen farelerden beslenen yavrular istatistiksel olarak anlamlı bir şekilde daha düşük büyüme göstermişlerdir. Ayrıca yetişkinliğe erişen farelerin ağırıklarında istatistiksel olarak anlamlı bir fark gözlenmediğinden dolayı genotipsel farkın burada ayırt edici bir faktör olmadığı da gösterilmiştir.

Laktasyonel hasar normal şartlarda oluşmaz. Histolojik değişimler, metabolik veya sekresyon yollarındaki hasarlar sonucu veya belli genlerin değişen regülasyonları ile oluşur. Bu hasarlar süt proteinlerinin transport mekanizmalarının, tight junction fonksiyonlarının, lipid metabolizmasının veya ilgili genlerin aktivasyonu sonucu hücresel ölüm ile gerçekleşir.

Şekil 3'te de anlaşılacağı gibi transgenik farelerde sekresyon hasarı görülmektedir. Bu durum ilk sütte yer alan ve emzirme ile alveolar gelişmeye sebep olan CLD'lerin alveollerin içinde sıkışık kalması ile ortaya çıkmaktadır (22).

Sekresyonun başlaması ile süt proteinlerinin ifadesi de artar (14). Şekil 4'te yüksek ET-1 ifadesinin WAP süt proteini ifadesini hem gebelikte hem de laktasyon periyodunda kuvvetli bir şekilde baskıladığı tespit edilmiştir. Bu durumu teyit etmek için laktasyon veya gebelik fizyolojisini taklit edecek bir hücre kültürü bulunmamaktadır. Ancak WAP knockout fare modellerinde de laktasyonel hasar olduğu Tripplett ve arkadaşları tarafından belirtilmiştir (23). Öte yandan beta kazein ifadesi gebelikte normal bir seviyedeyken laktasyonda düşüş göstermiştir. Bu düşüş sekresyonel hasara bağlı bir gelişme olarak yorumlanabilir. STAT5, WAP ve beta kazein ifadelerinde kritik bir role sahip olmasına rağmen (24) transgenik farelerde STAT5 aktivasyonunda herhangi bir değişime rastlanmamıştır (Şekil 6). Bu durum ET-1'in STAT5'ten bağımsız bir şekilde WAP ifadesine etki ettiğini gösterir. Ayrıca STAT5 aktivasyonuna rağmen beta kazeinin ifadesinin düşmesi bu iki protein için de STAT5 aktivasyonundan farklı bir mekanizma ile regüle olduğunu ortaya koymaktadır.

Laktasyon sırasında glukozun kandan alveoliye taşınması ve oradan laktoza dönüştürülüp süte aktarılması çok özel bir süreçtir. Bu süreçteki hasarlar sekresyon hasarı olarak ortaya çıkar. Bu bağlamda GLUT-1 en çok çalışılmış glukoz trasport proteinidir (22). Benzer bir şekilde Claudin-8 proteini tight junctionların kompozisyonlarının düzenlenmesinde ve gen regülasyonunda görev alır (25). Her iki protein için transgenik farelerde anlamlı bir fark bulunmamıştır. SREBF-1 yağ asitleri ve kolesterol biyosentezi için kritik bir regülatör proteindir $(19,22)$. Şekil 5'de görüldüğü gibi SREBF-1 ifadesi laktasyonda 9 kat artış göstermiştir. Ancak aynı artış gebelikte görülmediği için bu artış yüksek ET-1 ifadesi ile ilişkilendirilememektedir. Öte yandan AKT aktivitesi özellikle SREBF-1 gen ifadesini regülasyonunu sağlayarak lipid metabolizmasını kontrol eden önemli bir proteindir (19). AKT'nin özellikle gebelik ve laktasyon dönemlerinde regülasyo- nunun arttığı bilinmektedir (26). Şekil 7'de transgenik farelerde AKT aktivasyonu bakımından kontrol grubuna göre bir fark bulunmamaktadır. Bu bağlamda SERBF-1 in 9 kat artışının sebebi salgılanamayan CLD'lerden kaynaklanıyor olabilir. Ancak ilginç olarak AKT protein ifade seviyesi laktasyon periyodunda anlamlı bir düşüş sergilemektedir (Şekil 7D). Bu durum erken involusyonun bir habercisidir.

İnvolusyon daha önce de bahsettiğimiz gibi meme bezinin laktasyon periyodundan laktasyon olmayan periyoda geçişidir. Meme bezlerinde involusyon iki fazda gerçekleşir. İlk faz geri dönüşümlüdür ve lokal faktörlerin birikimi ile karakterize edilir (27).

Transgenik farelerde histolojik olarak fokal erken involusyon tespit edilmiştir. Pro-apoptotik faktörlerin ifadesi her ne kadar artış gösterse de süt emme devam ettiği için bu durum geri dönüşümlü olarak bir süre devam eder. Süt emmenin bitmesi ya da süt tıkanması ile hızlı bir şekilde involusyon sürecinin ikinci ve geri dönüşümü olmayan fazına geçilir. Bu süreci meme bezinde kontrol eden başlıca protein STAT3'tür. Şekil 8'de transgenik farelerde STAT3 aktivasyonu laktasyon sırasında tespit edilmiştir. Bu transgenik farelerin erken involusyona geçtiğini doğrulamaktadır.

STAT3'ün en temel aktivatörlerinden biri olarak bilinen LIF proteini ifadesinin gebelik ve laktasyon döneminde nerdeyse tespit edilemeyecek seviyelerde sentezlendiği bilinmektedir (28). ET-1 transgenik farelerde LIF proteini ifadesi gebelik ve laktasyon dönemlerinde anlamlı bir şekilde artış göstermektedir (Şekil 9). Öte yandan IL-6'nın ifadesinde herhangi bir değişim saptanmamıştır. Bu durum ET-1'in LIF ifadesi üzerinde etkisi olduğunu göstermektedir. Belki de bu nedenle fenotip olarak diğer transgenik modellere göre ET-1 transgenik model daha ağır bir laktasyonel hasar göstermektedir. Bu bulgu ET-1 ile LIF arasındaki etkileşimin in vitro analizlerinin yapılmasının ve bu moleküler mekanizma hakkında daha ayrıntılı çalışma yapılmasının önünü açmaktadır.

Etik Komite Onayı: Bütün hayvan deneyleri Charite Tıp Fakültesi Berlin'de gerekli izinler alınarak Alman hayvan koruma kanunlarına (Tierschutzgezetz) uygun bir şekilde gerçekleştirilmiştir.

Hakem Değerlendirmesi: Dış bağımsız.

Yazar Katkıları: Çalışma Konsepti - N.G., F.T.; Veri Toplama N.G.; Veri Analizi/Yorumlama - N.G., F.T.; Yazma - N.G., F.T.

Çıkar Çatışması: Yazarlar çıkar çatışması bildirmemişlerdir.

Finansal Destek: Yazarlar bu çalışmada finansal destek almadıklarını beyan etmişlerdir.

Ethics Committee Approval: All animal experiments were carried out in accordance with German animal protection laws (Tierschutzgezetz), with the necessary permissions from Charite Universitätsmedizin Berlin. 
Peer-review: Externally peer-reviewed.

Author Contributions: Concept - N.G., F.T.; Data Collection N.G.; Analysis and/or Interpretation - N.G., F.T.; Writing - N.G., F.T.

Conflict of Interest: The authors have no conflict of interest to declare.

Financial Disclosure: The authors declared that this study has received no financial support

\section{KAYNAKLAR/REFERENCES}

1. Muldoon TG. Prolactin mediation of estrogen-induced changes in mammary tissue estrogen and progesterone receptors. Endocrinology 1987; 121: 141-9. [CrossRef]

2. Robinson GW, Johnson PF, Hennighausen L, Sterneck E. The C/ EBPbeta transcription factor regulates epithelial cell proliferation and differentiation in the mammary gland. Genes Dev 1998; 12: 1907-16. [CrossRef]

3. Naylor MJ, Oakes SR, Gardiner-Garden M, Harris J, Blazek K, Ho TWC, et al Transcriptional changes underlying the secretory activation phase of mammary gland development. Mol Endocrinol 2005; 19: 1868-83. [CrossRef]

4. Yang ZZ, Tschopp O, Baudry A, Dümmler B, Hynx D, Hemmings BA. "Physiological functions of protein kinase B/Akt". Biochem Soc Trans 2004; 32(Pt 2): 350-4. [CrossRef]

5. Green KA \& Streuli $\mathrm{CH}$. Apoptosis regulation in the mammary gland. Cell Mol Life Sci 2004; 61(15): 1867-83. [CrossRef]

6. Watson CJ. Involution: apoptosis and tissue remodelling that convert the mammary gland from milk factory to a quiescent organ. Breast Cancer Res 2006; 8(2): 203. Epub 2006 Apr 10. [CrossRef]

7. Kritikou EA, Sharkey A, Abell K, Came PJ, Anderson E, Clarkson RW, et al. A dual, non-redundant, role for LIF as a regulator of development and STAT3-mediated cell death in mammary gland. Development 2003; 130(15): 3459-68. [CrossRef]

8. Yanagisawa $M$, Kurihara $H$, Kimura $S$, Tomobe $Y$, Kobayashi $M$, Mitsui Y., et al. A novel potent vasoconstrictor peptide produced by vascular endothelial cells. Nature 1988; 332(6163): 411-5. [CrossRef]

9. Itoh $\mathrm{Y}$, Kimura $\mathrm{C}$, Onda H, Fujino M. Canine endothelin-2: cDNA sequence for the mature peptide. Nucleic Acids Res 1989; 11; 17(13): 5389. [CrossRef]

10. Lam HC, Takahashi K, Ghatei MA, Bloom SR. Presence of immunoreactive endothelin in human milk. FEBS Lett 1990; 261(1): 184-6. [CrossRef]

11. Baley PA, Resink TJ, Eppenberger U, Hahn AW. Endothelin messenger RNA and receptors are differentially expressed in cultured human breast epithelial and stromal cells. J Clin Invest 1990; 85(4): 1320-3. [CrossRef]

12. Kozakai T, Sakate M, Masuo Y, Uchide T, Saida K. Increased gene expression of endothelin-1 and vasoactive intestinal contractor/ endothelin-2 in the mammary gland of lactating mice. Biochem Biophys Res Commun 2002; 297(5): 1339-43. [CrossRef]

13. Neville MC. Introduction: alpha-lactalbumin, a multifunctional protein that specifies lactose synthesis in the Golgi. J Mammary Gland Biol Neoplasia 2009; 14(3): 211-2. [CrossRef]

14. Rudolph MC, McManaman JL, Phang T, Russell T, Kominsky DJ, Serkova NJ, et al. Metabolic regulation in the lactating mammary gland: a lipid synthesizing machine. Physiol Genomics 2007; 28(3): 323-36. [CrossRef]
15. Blackman B, Russell T, Nordeen SK, Medina D, Neville MC. Claudin 7 expression and localization in the normal murine mammary gland and murine mammary tumors. Breast Cancer Res 2005; 7(2): R248-55. [CrossRef]

16. Seagroves TN, Hadsell D, McManaman J, Palmer C, Liao D, McNulty W, et al. HIF1 alpha is a critical regulator of secretory differentiation and activation, but not vascular expansion, in the mouse mammary gland. Development 2003; 130(8): 1713-24. [CrossRef]

17. Camps M, Vilaro S, Testar X, Palacín M Zorzano A. High and polarized expression of GLUT1 glucose transporters in epithelial cells from mammary gland: acute down-regulation of GLUT1 carriers by weaning. Endocrinology 1994; 134(2): 924-34. [CrossRef]

18. Maroulakou IG, Oemler W, Naber SP, Klebba I, Kuperwasser C, Tsichlis PN. Distinct roles of the three Akt isoforms in lactogenic differentiation and involution. J Cell Physiol 2008; 217(2): 468-77. [CrossRef]

19. Schwertfeger KL, Richert MM, Anderson SM. Mammary gland involution is delayed by activated Akt in transgenic mice. Mol Endo 2001; 15: 867-81. [CrossRef]

20. Clarkson RW, Wayland MT, Lee J, Freeman T, Watson CJ. Gene expression profiling of mammary gland development reveals putative roles for death receptors and immune mediators in postlactational regression. Breast Cancer Res 2004; 6(2): 92-109. [CrossRef]

21. Akira $S$, Nishio $Y$, Inoue $M$, Wang $X J$, Wei $S$, Matsusaka $T$, et al. Molecular cloning of APRF, a novel IFN-stimulated gene factor 3 p91 related transcription factor involved in the gp130-mediated Signaling pathway. Cell 1994; 77(1): 63-71. [CrossRef]

22. Anderson SM, Rudolph MC, McManaman JL, Neville MC. Secretory activation in the mammary gland: its not just about milk protein synthesis. Breast cancer research 2007; 9: 204. [CrossRef]

23. Triplett AA, Sakamoto K, Matulka LA, Shen L, Smith GH, Wagner $\mathrm{KU}$. Expression of the whey acidic protein (WAP) is necessary for adequate nourishment of the offspring but not functional differentiation of mammary epithelial cells. Genesis 2005; 43(1): 1-11. [CrossRef]

24. lavnilovitch E, Groner B, Barash I. Overexpression and forced activation of stat 5 in mammary gland of transgenic mice promotes cellular proliferation, enhances differentiation, and delays postlactational apoptosis. Mol Cancer Res 2002; 1(1): 32-47.

25. Furuse M, Hata M, Furuse K, Yoshida Y, Haratake A, Sugitani Y, et al. Claudin-based tight junctions are crucial for the mammalian epidermal barrier: a lesson from claudin-1-deficient mice. J Cell Biol 2002; 156(6): 1099-111. [CrossRef]

26. Creamer BA, Sakamoto K, Schmidt JW, Triplett AA, Moriggl R, Wagner KU. Stat 5 promotes survival of mammary epithelial cells through transcriptional activation of a distinct promoter in Akt1. Mol Cell Biol 2010; 30(12): 2957-70. [CrossRef]

27. Lund LR, Bjorn SF, Sternlicht MD, Nielsen BS, Solberg H, Usher PA, et al. Lactational competence and involution of the mouse mammary gland require plasminogen. Development 2000; 127: 448192.

28. Zhao L, Hart S, Cheng J, Melenhorst JJ, Bierie B, Ernst M, et al. Mammary gland remodeling depends on gp130 signaling through Stat3 and MAPK. J Biol Chem 2004; 279(42): 44093-100. [CrossRef]

29. Pfaffl MW, Horghan GW, Dempfle L. Relative expression software tool (REST) for group- wise comparison and statistical analysis of relative expression results in real-time PCR. Nucleic Acids Research 2002; 30(9): e36. [CrossRef] 